\title{
Hepatotoxic Activity of Essential Oil from Nutmeg (Myristica Fragrans) Against Tetrachloride-Induced Hepatic Damage In Mice
}

\author{
Essam F. Al-Jumaily ${ }^{1}$, Maytham H. A. Al-Amiry ${ }^{1}$, Jaleel I. Assad ${ }^{2}$ \\ ${ }^{I}$ Biotechnology Dept./ Genetic Engineering and Biotechnology Institute for postgraduate studies, Baghdad \\ University, IRAQ. \\ ${ }^{2}$ Center of Biotechnology Research / Al-Nahrain University, IRAQ.
}

\begin{abstract}
To extracting and purifying the essential oil containing terpenes from dried seeds of nutmeg Myristica fragrans available in Iraqi markets. Male albino mice $(n=44)$, with average weight $(25-28 \mathrm{~g})$ of about six weeks old The study also employed an in vivo evaluation of the hepatotoxic effect of essential oil in male albino mice at different concentrations ( 500 and $1000 \mathrm{mg} / \mathrm{kg}$ ) given orally for 7 days including biochemical functions serum glutamic pyruvic transaminase (SGPT), serum glutamic oxaloacetic transaminase (SGOT) and serum alkaline phosphatase (SALP) as parameters of liver function tests and serum total bilirubin (TSB). At day 8 the animal was sacrificed and the liver is weighed and kept in $10 \%$ formalin for preparation of histopathological sections. The serum was isolated from the blood for the biochemical tests. Statistical results showed the absence of any significant changes on body weight and liver weight of nutmeg treated mice. However nutmeg treated mice showed statistically significant alteration in the biochemical indicators of liver function including significant elevation in SAST, SALT, SALP and TSB in a dose dependent manner. The nutmeg essential oil carries a marked specific potential toxicity to the liver parenchyma, this is very important to be considered for further experimental and clinical studies.
\end{abstract}

Key words: Myristica fragrans, essential oil, Hepatotoxic, hepatic necrosis

\section{Introduction}

Nutmeg (NM) has its origins in the Spice Islands of Indonesia, formerly known as the spice islands, it is also cultivated in the Caribbean, south India, Sri Lanka, Sumatra, and Malaysia, It has been widely popular in Europe and India for its flavoring and medicinal properties [1].

Herbal preparations have become one the fast growing markets in the world and even in Iraq for alternative health products, there is a great potential misuse of these herbs and spices and there is no standardization of active constituents, herbs and spices can be viewed in terms of inherent toxicity like pennyroyal oil is used as an abortifacient but linked with hepatic necrosis similar to acetaminophen in toxic amounts, another example is chaparral which is used as antioxidant but linked with hepatic necrosis , cholestatic hepatitis and hepatic failure . [2].

The essential oil is highly sensitive to light and temperature and yields a colorless, pale yellow or pale green oil with a characteristic odor of nutmeg, the oil is soluble in alcohol and insoluble in water, the essential oil of East Indian nutmeg and West Indian nutmeg differ in their flavor and odor characteristics , the East Indian nutmeg oil is considered superior to the West Indian nutmeg oil, having a better aroma and a higher amount of phenyl propanoid ethers [3] and terpenes [4].

The essential oil extracted from nutmeg is a colorless or pale yellow thin liquid with the characteristic odor and taste of nutmeg Usually, it is obtained by steam distillation from ground nutmeg or from whole nutmegs graded as shrivels, rejects, or broken and wormy [5].

The acute oral LD50 of nutmeg oil in rats has been reported to be $2620 \mathrm{mg} / \mathrm{kg}$ [6] and $2600 \pm 220$ $\mathrm{mg} / \mathrm{kg}$ [7]. However, in another study, oil of nutmeg have been reported to have a rat oral LD50 value of 160 $\mathrm{mg} / \mathrm{kg}$ [8]. The Food and Drug Administration has reported oral LD50 values for other species including mice $(5620 \pm 520 \mathrm{mg} / \mathrm{kg})$ and hamsters $\sim(6000 \pm 230 \mathrm{mg} / \mathrm{kg})$, Cats seem to be highly sensitive to nutmeg and particularly to myristicin. A 5-10 g oral dose of nutmeg will cause death in cats, while $50 \mathrm{mg} / \mathrm{kg}$ of myristicin intraperitoneally (i.p) will result in death [9]. Most of the major components of nutmeg have established LD50 values. With the exception of myristicin, which has a reported LD50 of approximately $570 \mathrm{mg} / \mathrm{kg}$, most of the other identified components of nutmeg have LD50 values in excess of $1300 \mathrm{mg} / \mathrm{kg}$ [6].

The aim of this study is to evaluating the physicochemical characteristics of the essential oil extract and study the effect in mice compared to that caused by carbon tetrachloride as a hepatotoxic model. 
Hepatotoxic Activity of Essential Oil from Nutmeg (Myristica fragrans) Against tetrachloride-

\section{Materials and Methods}

Dried seeds of Myristica fragrans were collected from local market in Baghdad during September / 2009 and identified by the botanist professor Ali Almosawi, Department of Biology, College of Sciences / Baghdad University. The extract was prepared according to Harborne,[10]. with some modification. 50 gram of the crude powder of seeds was refluxed with $350 \mathrm{ml}$ of $70 \%$ methanol (1:7) in soxhlet apparatus for 8 hours. The extract was than filtered through a filter paper and evaporated to dryness under vacuum at $40 \mathrm{C}^{\circ}$, and the dried extract was weighed and stored at $4 \mathrm{C}^{\circ}$. [11].

The yield percentage of essential oil was determined using the formula described by Rao et al.,[12] where the amount of essential oil recovered (g) was determined by weighing the oil after moisture was removed:

Percentage yield $(\%)=$ Amount of essential oil recovered $(\mathrm{g}) * 100 /$

Amount of plant material distilled $(100 \mathrm{~g})$.

The physical futures were evaluated according to the methods mentioned Al-Shahhat,[13]. and used for studying hapatoprotective.

Mice weighting between 25-28 gm about six weeks old obtained from the Institute of Embryo Researches and Infertility Treatment/ Al-Nahrain University were used as animal models. The mice divided into four groups, each group consisting of 10 animals. Hepatoprotective activity of Myristica fragrans was evaluated using CCI4 -induced model Krishnamoorthy and Rema [14]. Group one was kept on normal diet and served as control, the second group received CCI4 $(0.5 \mathrm{ml} / \mathrm{kg})$ orally to induce liver damage in mice and served as positive control, the third and fourth group received Myristica fragrans essential oil extract 500 and 1000 $\mathrm{mg} / \mathrm{kg}$ respectively once daily, for eight days.

\subsection{Acute toxicity testing :}

The nutmeg essential oil extract was administered in a dose of 500,1000, $\mathrm{mg} / \mathrm{kg}$ to groups of mice $(\mathrm{n}=5)$ and the number of animals dying within $24 \mathrm{hr}$ was observed in each group [15].

\subsection{Preparation and analysis of samples for evaluation of hepatic injury:}

The serum enzymes tests that have proved useful for evaluation of experimentally- induced hepatic injury according to [16].

\subsection{Preparations of Post-mortum Serum Samples:}

After sacrificing the animals by anesthetic ether, blood was collected from the animals by intracardiac puncture using insulin syringe. The clot was dispersed with glass rod and then centrifuged at 3000 $\mathrm{rpm}$ for 15 minute; the serum was used for the estimation of serum glutamic pyruvic transaminase (SGPT),serum glutamic oxaloacetic transaminase (SGOT) and serum alkaline phosphatase (SALP) as parameters of liver function tests and serum total bilirubin (TSB) as excretory function test [17]. The blood obtained from each mice ranging from $0.7-1 \mathrm{ml}$.

\subsection{Histopathological Examination:}

Liver tissues were prepared for histopathological examination according to Provan and Krentz [18] using paraffin sections technique. Liver samples were fixed in $10 \%$ formaldehyde solution, and then dehydrated using increasing strengths of ethanol $(70 \%, 80 \%, 90 \%$ and $100 \%)$ for two hours each. Cleaning of tissues using xylene were done, then impregnated with paraffin wax, heated for two hours in the oven at $60 \mathrm{C}^{\circ}$ and blocked by pouring in embedded models. Blocks were cut by microtome (Reichert Jung) into 5 micron thick sections, floated in water bath and left in oven for dewaxing, hydrated using decreasing strengths of ethanol ( $90 \%, 80 \%$ and $70 \%$ ) for 10 minutes each, stained with haematoxyline and eosin, and examined under light microscope.

\subsection{Statistical Analysis:}

The significance of differences between the mean values was calculated using unpaired Students't-test. Multiple group comparisons were made using analysis of variance (ANOVA) [19]. 


\section{Results And Discussion}

The results shows that the odor of the essential oil from Myristica fragrance obtained is strong, turpentine like odor or spicy. Each essential oil is characterized by a special odor which attributed to the presence of some low molecular weight compounds like alcohols, esters, phenols and oxygenated compounds which have the future of being highly volatile at room temperature $[13 ; 20]$.

The essential oils of plants differ in their colors and the degree of colors, they are either colorless, pale yellow, ( like the essential oil of Coriander and anise), light yellow ( like the essential oil of peppermint ) , greenish yellow ( like Japanese mint and celery), yellowish brown ( like the essential oil of cumin and dill ), or blue or greenish blue ( like Camomile and Achillea flowers) [21] .

The specific gravity of the studied essential oil was 0.890,Sarath-kumara [22] have mentioned that the specific gravity of the East Indian Nutmeg oil ranges from 0.885 to 0.915 and that of west Indian has been 0.860 to 0.88 at $20^{\circ} \mathrm{C}$. Leela [14] has also report that the specific gravity of east Indian oil is ranging from 0.880 to 0.913 and that of west Indian is ranging from 0.859 to 0.865 .

The refractive index of the nutmeg essential oil is found to be 1.4822, Leela [14], has reported that the refractive index of the East Indian Nutmeg essential oil is ranging from 1.4776 - 1.4861, while that of West Indian Nutmeg essential oil is ranging from 1.4729 - 1.4746. It is consider one of the important features to evaluate the quality and purity of oils and fats, the increasing in the refractive index value is a feature of high quality oils, and it is increased with increasing of the specific gravity of the oil and affected by the change in the concentrations of its components, especially the solid compounds.[23].

Myristicin Purification it was done using silica gel G60 column chromatography technique with a mobile phase n-hexane: benzene: ethyl acetate, methanol to elute fractions according to their affinity to mobile phase. The resultant fractions that give positive ferric chloride test $1 \%$ solution (fraction II) are detected by T.L.C silica gel $60 \mathrm{~F}_{254}$ plate of $0.75 \mathrm{~mm}$ thickness using the mobile phase $\mathrm{n}$-hexane-chloroform (3:2), the TLC chromatogram in (Fig 1) for the fraction of the positive result (FII) and the standard have given one brown spot of $\mathrm{R} f 0.71$ in $\mathrm{n}$-hexane-chloroform (3:2) as mentioned by Harborn [10].

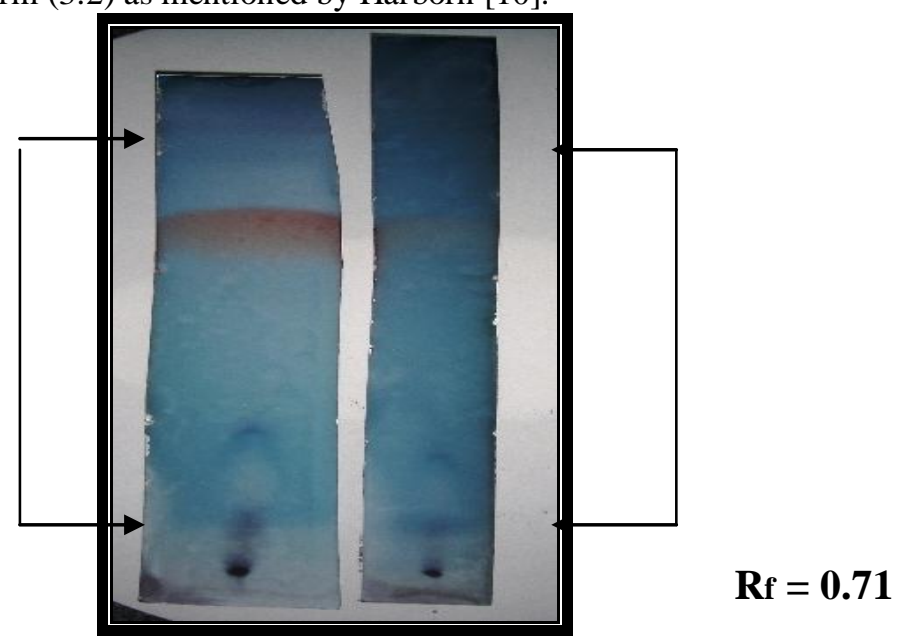

Figure (1): T.L.C. of the standard Myristicin (left) and the purified Myristicin (right) in n-hexane - chloroform mobile phase, the brown spot of $\mathrm{R} f 0.71$ indicate the presence of myristicin [10].

Gas Chromatography (GC) for Essential oil and Myristicin

The GC chromatogram for the purified Myristicin as in (Fig 2) shows the presence of one main peak of conc. of $97.6 \%$. (Table 1).

The applied GC for the essential oil and purified myristicin, According to the GC analysis of the essential oil and the purified myristicin, the percentage of myristicin in the essential oil was about $6 \%$. Therefore it can be assumed that the nutmeg is from East India [25].Particularly may be from Singapore (Table 1)[26].

Although the seeds are imported to Iraq from India but India itself imported it from south-east Asian countries because nutmeg trees are not grown to any large extent in India [27]. Reineccius [25] has reported that the myristicin content of East Indian nutmeg is $3.3-13.5 \%$ of the essential oil while of West Indian nutmeg is 0.5$0.8 \%$ of the essential oil and that of Sri-Lanka origin is $3.8 \%$. 


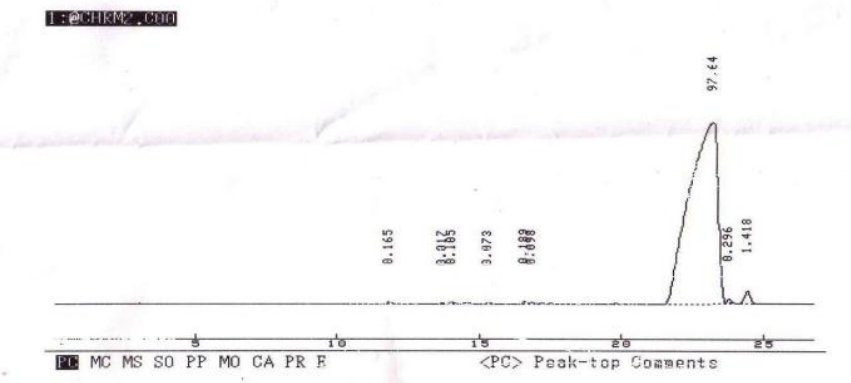

Figure 2 : GC of the purified Myristicin after T.L.C.

Table 1: Retention time for the purified Myristicin (myristicin peak appeared after 23.194 minutes with concentration of (97.6399)

\begin{tabular}{|l|l|l|l|l|}
\hline Peak no. & Time & Area & Height & Conc. \\
\hline 1 & 11.32 & 2443 & 231 & 0.1649 \\
\hline 2 & 13.378 & 256 & 30 & 0.0172 \\
\hline 3 & 14.006 & 1549 & 159 & 0.1046 \\
\hline 4 & 15.317 & 1080 & 115 & 0.0729 \\
\hline 5 & 16.608 & 2804 & 274 & 0.1892 \\
\hline 6 & 16.83 & 1454 & 141 & 0.0981 \\
\hline 7 & 23.194 & 1446608 & 1211 & 97.6599 \\
\hline 8 & 23.783 & 4380 & 411 & 0.2956 \\
\hline 9 & 24.44 & 21083 & 1483 & 1.4176 \\
\hline Total & & 1481574 & 24060 & 100 \\
\hline
\end{tabular}

Table (2) shows the results of body weight (gm) of mice before and after treatment. CCl4 - treated mice show no significant $(p<0.05)$ decrease in the mean of body weight compared to control group . Mice treated 500 and $1000 \mathrm{mg} / \mathrm{kg}$ essential oil of NM seeds have showed no significant $(\mathrm{p}<0.05)$ differences in the means of body weights at the end of seven days of treatment compared to the control group.

The absence of a significant body weight reduction may be due to the stomachic effect of nutmeg seeds, however the absence of significantly increase in body weight may be due to the short term treatment although relatively highly dosage used [28].

Table 2: Effect of different doses of myristica fragrans essential oil extract on the body weight in mice before and after treatment

\begin{tabular}{||l||l||l||l||}
\hline Treatment & $\begin{array}{l}\text { Dose } \\
(\mathrm{mg} / \mathrm{kg})\end{array}$ & $\begin{array}{l}\text { Weight( gm) } \\
\text { before treatment }\end{array}$ & $\begin{array}{l}\text { Weight(gm) } \\
\text { after treatment }\end{array}$ \\
\hline \hline Control & --- & $25.40 \pm 1.90^{\mathbf{a}}$ & $26.90 \pm 1.90^{\mathrm{a}}$ \\
\hline $\mathbf{C C l}_{\mathbf{4}}$ & --- & $25.70 \pm 2.40^{\mathrm{a}}$ & $25.20 \pm 3.10^{\mathrm{a}}$ \\
\hline $\begin{array}{l}\text { Essential oil }+ \\
\mathbf{C C l}_{\mathbf{4}}\end{array}$ & $\begin{array}{l}500 \\
\mathrm{mg} / \mathrm{kg}\end{array}$ & $28.10 \pm 1.90^{\mathrm{a}}$ & $27.90 \pm 1.40^{\mathrm{a}}$ \\
\hline $\begin{array}{l}\text { Essential oil }+ \\
\mathbf{C C l}_{\mathbf{4}}\end{array}$ & $\begin{array}{l}1000 \\
\mathrm{mg} / \mathrm{kg}\end{array}$ & $27.10 \pm 2.20^{\mathrm{a}}$ & $28.60 \pm 2.00^{\mathrm{a}}$ \\
\hline
\end{tabular}

Each value represent mean $+\mathrm{SD}$

Values with non-identical superscripted $(a, b, c, d, e \& f)$ are considered as significantly different $(p<0.05) N=$ 10 animals each group.

\subsection{Effect of NM essential oil on the activity of serum aspartate aminotransferase (AST) and alanin aminotranferase (ALT)}

Carbon tetrachloride-treated mice (group II) showed a significantly $(\mathrm{P}>0.05)$ increase in the serum activity of AST compared with control mice (group I) (Table 3). Mice treated with $500 \mathrm{mg} / \mathrm{kg}$ and $1000 \mathrm{mg} /$ $\mathrm{kg}$ of essential oil show a significant ( $p>0.05$ ) increase in the level of AST as compared to the control group but 
Hepatotoxic Activity of Essential Oil from Nutmeg (Myristica fragrans) Against tetrachloride-

still significantly less than carbon tetrachloride - treated mice . Also there is a significant ( $p>0.05)$ increase in the serum activity level of AST between the different doses of NM essential oil $(500 \mathrm{mg} / \mathrm{kg}$ and $1000 \mathrm{mg} / \mathrm{kg}$ ) for 7 days in the serum activity level of AST (77.83 and $94.48 \mathrm{U} / 1$ respectively) as compared to the control group but still significantly less than $\mathrm{CCl} 4$ treated group.

Mice treated with 500 and $1000 \mathrm{mg} / \mathrm{kg}$ of essential oil show a significant ( $>0.05)$ increase in the level of ALT as compared to the control group but still significantly less than carbon tetrachloride - treated mice.

Table 3. show a significant ( $p>0.05$ ) increase in the serum activity level of ALT between the different doses of NM essential oil (500 mg / $\mathrm{kg}$ and $1000 \mathrm{mg} / \mathrm{kg}$ for 7 days) in the serum activity (49.85 U/l and $60.95 \mathrm{U} / \mathrm{l}$ respectively ) as compared to the control group but still significantly less than CCl4-treated group .

Table 3: Effect of different doses of myristica fragrans essential oil on the activity of serum AST and ALT in mice

\begin{tabular}{|l||l||l|l||}
\hline Treatment & $\begin{array}{l}\text { Dose } \\
(\mathrm{mg} / \mathrm{kg})\end{array}$ & AST ( SGOT) U/l & ALT ( SGPT) U/l \\
\hline \hline Control & --- & $61.9 \pm 0.8^{\mathbf{e}}$ & $33.5 \pm 1.1^{\mathbf{f}}$ \\
\hline $\mathbf{C C l}_{4}$ & --- & $195.0 \pm 4.3^{\mathbf{a}}$ & $110.10 \pm 2.8^{\mathbf{a}}$ \\
\hline $\begin{array}{l}\text { Essential oil + } \\
\mathbf{C C l}_{4}\end{array}$ & $\begin{array}{l}500 \\
\mathrm{mg} / \mathrm{kg}\end{array}$ & $77.83 \pm 1.8^{\mathbf{c}}$ & $49.85 \pm 0.89^{\mathbf{c}}$ \\
\hline $\begin{array}{l}\text { Essential oil + } \\
\mathbf{C C l}_{4}\end{array}$ & $\begin{array}{l}1000 \\
\mathrm{mg} / \mathrm{kg}\end{array}$ & $101.48 \pm 3.4^{\mathbf{b}}$ & $60.95 \pm 1.9^{\mathbf{b}}$ \\
\hline
\end{tabular}

Each value represent mean $+\mathrm{SD}$

Values with non-identical superscripted $(a, b, c, d, e \& f)$ are considered as significantly different $(p<0.05) \mathrm{N}=$ number of animals.

In (Table 3) there is a significant ( $p>0.05$ ) increase in the serum activity level of ALT between group IV and V (methanolic extract $1000 \mathrm{mg} / \mathrm{kg}$ and essential oil $500 \mathrm{mg} / \mathrm{kg}$ respectively ) (43.42 $\mathrm{U} / 1$ and $49.85 \mathrm{U} / 1$ respectively).

The data presented in the present work clearly demonstrate the state of oxidative stress induced in hepatic tissues by $\mathrm{CCl}_{4}$, as a result of the increased lipid peroxidation and subsequent degradation of biomembranes, the permeability of the plasma membranes was severely affected, and may lead to leakage of AST and ALT and an increasing in their activities in the serum [29].

Mice treated with 500 and $1000 \mathrm{mg} / \mathrm{kg}$ of Nutmeg essential oil showed an increase in the level of AST and ALT, as compared to control group, the level of these biochemical indicators was increased significantly with the increasing dose of the extract and was more with oil treated mice even between the $500 \mathrm{mg} / \mathrm{kg}$ of oil and $1000 \mathrm{mg} / \mathrm{kg}$.

These findings agreed with Al-Hamzi et al [29] who reported that, treatment of mice with 20,40 and $80 \mathrm{mg} / \mathrm{kg}$ of myristica fragrans extract intraperitonial (i.p) showed statistically significant alteration in the biochemical indicators of liver function including, and reduction of total protein and serum albumin and significant elevation of SGOT and SGPT .

\subsection{The effect of NM seeds essential oil on serum alkaline phosphatase (ALP) activity and total serum bilirubin (TSB).}

Carbon tetrachloride -treated mice show a significantly $(p>0.05)$ increase in the serum activity level of ALP as compared to control mice .( Table 4)

Mice treated with 500 and $1000 \mathrm{mg} / \mathrm{kg}$ of essential oil show a significant ( $p>0.05$ ) increase in the serum activity level of ALP (group V and VI respectively) as compared to control group, but significantly less than $\mathrm{CCl} 4$-treated group.

Table (4) shows a significant increase in the serum activity level of ALP between the different doses of essential oil (500 and $1000 \mathrm{mg} / \mathrm{kg}$ for 7 days) (81.50 and $95.60 \mathrm{U} / \mathrm{l}$ respectively).

Total serum bilirubin level (TSB) has shown a significant increase in CCl4 treated mice. As compared to control mice (Table 4).

Mice treated with $500 \mathrm{mg} / \mathrm{kg}$ and $1000 \mathrm{mg} / \mathrm{kg}$ of essential oil show a significant $(\mathrm{p}>0.05)$ increase in the level of TSB ( 0.52 and $0.69 \mathrm{mg} / \mathrm{dl}$ respectively $)$ as compared to the control group but still significantly less than carbon tetrachloride - treated mice . 
Hepatotoxic Activity of Essential Oil from Nutmeg (Myristica fragrans) Against tetrachloride-

Table (4) shows a significant ( $\mathrm{p}>0.05$ ) increase in the serum level of TSB between the different doses of NM essential oil (500 and $1000 \mathrm{mg} / \mathrm{kg}$ for 7 days) in the serum level $(0.52$ and $0.69 \mathrm{mg} / \mathrm{dl}$ respectively ) as compared to the control group but still significantly less than CCl4-treated group .

Table 4: Effect of different doses of myristica fragrans essential oil on the activity of serum ALK and TSB in mice

\begin{tabular}{|l||l||l|l||}
\hline Treatment & $\begin{array}{l}\text { Dose } \\
(\mathrm{mg} / \mathrm{kg}\end{array}$ & ALK U/l & TSB mg/dl \\
\hline \hline Control & -- & $64.03 \pm 1.5^{\mathbf{f}}$ & $0.34 \pm 0.02^{\mathbf{f}}$ \\
\hline $\mathbf{C C l} \mathbf{4}_{\mathbf{4}}$ & -- & $157.00 \pm 5.6^{\mathbf{a}}$ & $1.30 \pm 0.06^{\mathbf{a}}$ \\
\hline essential oil $+\mathbf{C C l}_{\mathbf{4}}$ & $\begin{array}{l}500 \\
\mathrm{mg} / \mathrm{kg}\end{array}$ & $85.50 \pm 1.1^{\mathbf{c}}$ & $0.52 \pm 0.01^{\mathbf{c}}$ \\
\hline essential oil $+\mathbf{C C l}_{\mathbf{4}}$ & $\begin{array}{l}1000 \\
\mathrm{mg} / \mathrm{kg}\end{array}$ & $95.60 \pm 1.5^{\mathbf{b}}$ & $0.69 \pm 0.001^{\mathbf{b}}$ \\
\hline
\end{tabular}

Each value represent mean $+\mathrm{SD}$

Values with non-identical superscripted (a, b, c, d , e\& f ) are considered as significantly different $(\mathrm{p}<0.05)$ $\mathrm{N}=10$ animals in each group.

ALP has widespread tissue distribution, although serum level are thought to be primarily from liver and bone, the increased hepatic ALP is usually associated with biliary system damage, elevated serum ALP can be caused by increased synthesis or release of ALP or by accumulation of bile acids because of biliary obstruction, bile acids can also damage cellular membranes, cause releasing of intracellular ALP. [30].

Total serum bilirubin (TSB), have been increased significantly in $\mathrm{CCl}_{4}$-treated mice (Table 4) due to hepatic cellular damage which leads to disability of liver cells to metabolize and excrete bilirubin [31].

\subsection{Histological examinations of the liver sections:}

Section of mice liver treated with $2 \%$ tween 80 (control group) show normal application of hepatocyes cells with slight accumulation of glycoprotein arrange around the central vein (no significant pathological changes) (Figure 3).

The histological examination of liver sections from each animal treated with $\mathrm{CCl}_{4}$, has showed a wide area of sever ballooning degeneration necrosis of hepatocyte( bridging necrosis), bile duct proliferation, sever cholestasis especially around central vein with inflammatory cells and steatosis (Figure 3) as compared with control group .

Section of mice liver treated with $500 \mathrm{mg} / \mathrm{kg}$ of myristica fragrans essential oil for 7 days has showed focal area of degeneration and necrosis with infiltration of mononuclear cells and bile duct proliferation and also section of mice liver treated with $1000 \mathrm{mg} / \mathrm{kg}$ has showed more degenerative changes and necrosis of hepatocyes with focal mononuclear cells infiltration and bile duct proliferation (Figure 3).
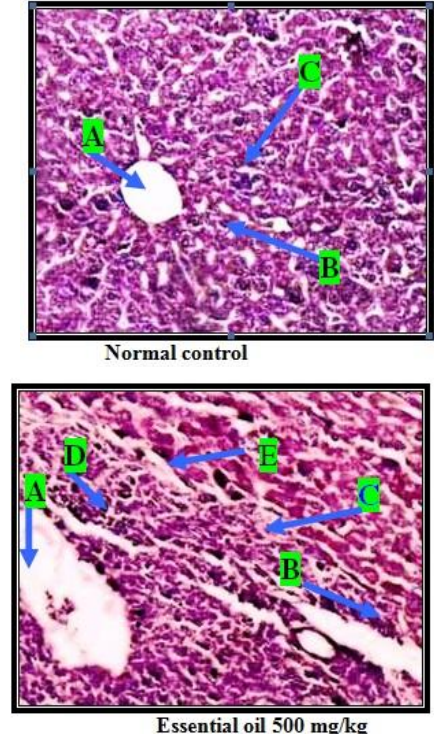

Figure 3: Histopathological studies of the mice liver treated with essential oil.

Magnification: (10x20), staining: Haematoxylline \& Eosin.
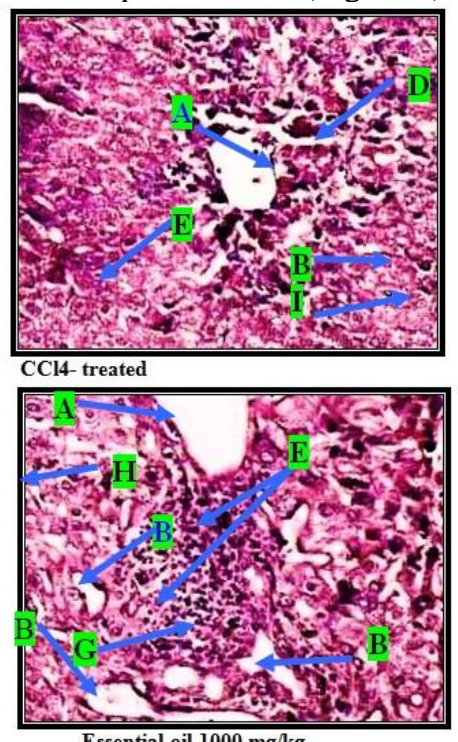
Hepatotoxic Activity of Essential Oil from Nutmeg (Myristica fragrans) Against tetrachloride-

\begin{tabular}{ccl}
\multicolumn{2}{c}{ A: central vein } & \multicolumn{2}{c}{ B bile duct proliferation } & \multicolumn{1}{c}{ C: hepatic cells ( hepatocytes) } \\
$\begin{array}{ccl}\text { B: necrosis } \quad \text { I: fatty change } & \text { D: inflammatory cells } & \text { E: ballooning degeneration } \\
\text { G: inflammatory cells } & \text { H: fatty changes } & \text { E: necrosis }\end{array}$
\end{tabular}

Concerning histological examination seen in the livers of animals treated with $\mathrm{CCl}_{4}$, the current work showed that, there was hepatic degeneration with necrosis in portal zone, fatty changes with wide dispersion of inflammatory cells (Figure 3).

Fatty degeneration (steatosis), observed in liver of mice intoxicated by $\mathrm{CCl}_{4}$ may be attributed to the inhibitory effect of $\mathrm{CCl}_{4}$ on lipoproteins secretion especially very low density lipoprotein (VLDL) from hepatocytes into circulation [32].

While sections of liver treated with 500 and $1000 \mathrm{mg} / \mathrm{kg}$ of Nutmeg essential oil show more destructive changes i.e. more degenerative changes and necrosis of hepatocytes with infiltration of mononuclear cells and bile duct proliferation. Although nutmeg is used as aphrodisiac in traditional medicine, the oral administration of its essential oil lead to antifertile state and histopathological changes in male rats testes due to the interference of the oil in the testicular androgen level, which could recover after termination of the treatment [33] .

The actual mechanism by which nutmeg induced cellular degeneration observed in this experiment needs further investigation. The necrosis observed is probably due to the high concentration of nutmeg on the liver. Pathological or accidental cell death is regarded as necrotic and could result from extrinsic insults to the cell as osmotic thermal, toxic and traumatic effect ,Physiological cell death is regarded as apoptotic and organized programmed cell death (PCD) that is mediated by active and intrinsic mechanisms [34].

\section{CONCLUSION}

It can be concluded that nutmeg essential oil carries a marked specific potential toxicity to the liver parenchyma and to less extent the methanolic extract, this is very important to be considered for further experimental and clinical studies. The medicinal use of nutmeg and its use as a spice suggest that it contains some constituents which are responsible for the reported biological activities. Some of these active principles may at the same time possess adverse effects when dosage is abused.

[1] D.G. Barceloux D.G.Medical Toxicology of Natural Substances: foods, fungi, medicinal herbs, plants, and venomous animals. (U.S.A. John Wiley and Sons Inc. 2008).

[2] J.Brent, K.L.Wallace, K.K.Burkhat, S.D.Phillips and J.W.Donavan. (2004). Critical Care Toxicology: diagnosis and management of the critically poisoned patient. ELSEVIER MOSBY. 2004.;1305-

[3] Y. Masada, Y.Application of Gas-Liquid Chromatography Mass Spectrometry to the Identification of Essential Oils. (New York, Plenum Press, John Wiley and Sons. 1976).

[4] Y.S. Lewis .Nutmeg and mace. In: Spices and Herbs for the Food Industry. (England, Food Trade Press. 1984).

[5] K.T. Farrell. (1985). Spices, Condiments, and Seasonings. (Westport: AVI Publishing Co. 1985).

[6] P.M.Jenner, E.C.Hagan, J.M. Taylor, E.L. Cook and O.G. Fitzhugh. (1964). Food flavoring and compounds of related structure. Food Cosmet. Toxicol. 2 1964. 327-43.

[7] National Technical Information Service. GRAS (Generally Recognized As Safe) Food Ingredients - Oil of Nutmeg and Myristica Oil. Food and Drug Research Labs, Inc. 1972.

[8] National Technical Information Service.Mutagenic Evaluation of Compound FDA 71-28, Oil of Nutmeg, Litton Bionetics, Inc . 1974.

[9] J.A. McCord and L.P. Jervey. Nutmeg (myristicin) poisoning: a case report. J. S. Carolina Med. Assoc. 58: 1962. 436-439.

[10] J.B.Harborne. Phytochemical Methods: a guide to modern techniques of plant analysis.(UK.Chapman and hall. 1998)

[11] M. H.A. Al-Amiry. Extraction and purification of terpenes from nutmeg (myristica fragrans) and study its effect on laboratory animals (in vivo). The Institute of Genetic Engineering \& Biotechnology for Postgraduate Studies, University of Baghdad. Iraq. M.Sc. thesis. 2010.

[12] B.R.R.Rao, P.N. Kaul, K.V. Syamasundar and S. Ramesh. "Chemical profiles of primary and secondary essential oils of palmarosa (Cymbopogon martinii (Roxb.) Wats. var motia Burk.)." Industrial Crops and Products 21(1). $2005.121-127$.

[13] N.A.Al-Shahhat. The Volatile Oils. (Egypt. Arabic House for Publishing and Distribution. 2000).

[14] B.Krishnamoorthy and J. Rema. (2000). Nutmeg and mace. (In: Peter, K.V.(ed.) Handbook of Herbs and Spices. CRC Press, New York 2000).

[15] N.K. Leela. Nutmeg and mace. In: Chemistry of Spice. (eds.) Parthasarathy V. A., Chempakam B. and Zachariah T.J. 2008. UK. Biddles Ltd, King's Lynn. Pp : 165-189.

[16] M.T. Olaleye, C. Afolabi, A. Akinmoladun, A. Akindahunsi. Antioxidant properties of Myristica fragrans Houtt. and its effect on selected organs of albino rats. African Journal of Biotechnology. 5 : 2006. 1274- 1278.

[17] Y. Ozaki, S. Soedigdo, Y.R. Wattimena and A.G. Suganda. Antiinflammatory effect of mace, aril of Myristica fragrans Houtt. and its active principles. Japan J. Pharmacol. 49: 1989. 155-163.

[18] D.Provan and A. Krentz. Oxford Handbook of Clinical and Laboratory Investigation.(Oxford . 2002).

[19] R.C.Dunean; R.G. Knapp and M.C.Millerill. Introductory biostatistics for the health sciences (Wiley Medical publication.1983)

[20] V.S.Venturella. Natural products (In: Remington: The science and practice of pharmacy. (Edt, Gennaro, A.R.)20th ed. Lippincott, Williams and Wilkins. USA. 2000)

[21] A.H.I.Al-Azawi. Chemical study of Ocimum basilicum extracts and evaluation of its activity on some pathogenic microorganisms. Genetic Engineering and Biotechnology Institute for Post Graduate Studies, Baghdad University.M.Sc.thesis 2006.

[22] S.J.Sarath-Kumara, E.R.Jansz and H.M. Dharmadsa. Some physical and chemical characteristics of Sri Lankan nutmeg oil. J. Sci. Food Agric. 36, 1985. 93-100. 
Hepatotoxic Activity of Essential Oil from Nutmeg (Myristica fragrans) Against tetrachloride-

[23] S.A.Ihsan. Study of some factors affecting the quantitative and qualitative characteristics of volatile oils in mint and watermelon.. Faculty of Agriculture / Baghdad University. PhD. dissertation . 1999.

[24] G.Reineccius. Source Book of Flavors. ( USA. .Aspen Publishers .1999)

[25] Y.S. Lewis. Nutmeg and mace. In: Spices and Herbs for the Food Industry. (Food Trade Press. England. 1984).

[26] R.Singh (2006).Psychoactive Medicinal Plants: hallucinogenic and narcotic drugs. Global vision publishing house. India. Pp: 206209.

[27] M.A.Al-Hamzi, A.I.Assaggaf, G.N.E. Al-Sayed, and Y.S. Bin-Naser. (2004). Effect of acute and subchromnic administration of nutmeg seeds extract on mice behaviour, Histological structure and Biochemical functions .Saudi. j. Biol. Sci.,11, 2, 2004.177187.

[28] N.Aghel, I. Rashidi and A. Mombeini. Hepatpprotective Activity of Capparis spinosa Root Bark against CCl4 Induced Hepatic Damage in Mice. Iranian journal of pharmaceutical research , 6(4): 2007. 285-290.

[29] A.J. Harris A.J. Hepatic toxicology In: Toxicology Principles for The Industrial Hygienist. (Eds.). Luttrell W.E., Jederberg W.W. and still K.R. AIHA .U.S.A. 2008)

[30] M.G.Sethurman, K.G. Latitha and B. Rajkapoor. Hepatoprotective activity of sarcotstemma brevistigma against carbon tetrachloride - induced hepatic damage in rats . Curr.Sci. 84(9): 2003. 1186-1187.

[31] M. Boll, L.W.D.Weber, E. Becker, and A. Stampfl. Hepatocyte damage induced by carbon tetrachloride: inhibited lipoprotein secretion and changed lipoprotein composition. Z. Naturforsch. 56: 2004. 283- 290.

[32] M. Agarwal, A. Chauhan, and T. Gehani. Effects of myristica fragrans oil on reproductive organs of male albino rats. Pharmaceutical Biology; 47(6): 2009. 509-515.

[33] A.O.Eweka and A. Eweka. (2010). Histological effects of oral administration of nutmeg on the kidneys of adult Wister rats. North American Journal of Medical Sciences. 2. 4. 2010. 189-192. 